\title{
Hemorrhagic and Necrotizing Pleurisy as the Cause of Death of a Migrating Wolf
}

\author{
Anna Lukomska1*, Katarzyna Serwańska-Leja², Tomasz Uzar², Bartosz Perz ${ }^{3,4}$, \\ Grzegorz Paczkowski ${ }^{4}$, Emilian Małek ${ }^{1}$, Marcin Komosa ${ }^{2}$, Marek Houszka ${ }^{1}$ \\ ${ }^{1}$ Department of Preclinical Sciences and Infectious Diseases, Faculty of Veterinary Medicine and Animal Science; \\ Poznan University of Life Sciences, Wołyńska 35, 60-637 Poznań, Poland \\ ${ }^{2}$ Department of Animal Anatomy, Faculty of Veterinary Medicine and Animal Science, \\ Poznan University of Life Sciences, Wojska Polskiego 71c, 60-625 Poznań, Poland \\ ${ }^{3}$ Department of Silviculture, Faculty of Forestry and Wood Technology; Poznań University of Life Sciences, \\ Wojska Polskiego 69, 60-625 Poznań, Poland \\ ${ }^{4}$ Forest Inspectorate of Turek, Chopina 70, 62-700 Turek, Poland
}

Received: 21 February 2021

Accepted: 15 April 2021

\begin{abstract}
The restoration of the distribution range of the gray wolf (Canis lupus) creates the possibility of gene exchange in the wolf's various populations, and biodiversity in the environment. At the beginning of May 2020, in the Turek Forest District, an atypically behaving young individual was registered. The wolf was found dead after four days of observation. A radiographic examination of the body was performed, followed by an autopsy and histopathological and cytopathological examination of the lungs and pleural effusion. Post-mortem examination revealed a significant amount of cloudy fluid with blood in the pleural cavity. The lungs were sunken and showed a series of lesions indicative of inflammation. The diagnosis was confirmed by a histopathological examination and smear of pleural fluid. The laboratory tests revealed the presence of bacteria with the morphological features of Streptococcus spp. and Enterococcus spp. The changes found in the study indicate that fibrinhaemorrhagic-necrotizing pleurisy was the primary process and the cause of the wolf's death. The circumstances described indicate that the tested wolf was an individual rejected by the pack, who migrated alone. Decreased immunity, possibly caused by stress and malnutrition, caused the proliferation of opportunistic bacteria that eventually led to pleurisy and death.
\end{abstract}

Keywords: grey wolf (Canis lupus), migration, pleurisy, hydrothorax, camera trap

*e-mail: anna.lukomska@up.poznan.pl 


\section{Introduction}

The gray wolf (Canis lupus), exterminated in most of its natural habitats in Europe, has recently been restored over much of its historic range. Currently, there is an exceptionally dynamic increase in the wolf population in the western part of the Great European Plain. What is more, the area of central Poland can be considered an area where wolves from different geographic locations meet. They are individuals of Carpathian, Western and Eastern lowlands origin [1]. This fact is of great importance for ecologically significant reasons, such as the maintenance of environmental biodiversity or the possibility of exchanging genes of different wolf populations. However, health-related factors are no less important, as evidenced by some studies reporting that mountain populations are characterized by a different susceptibility to parasitic invasions than lowland ones [2]. Thus, migrating wolves can naturally spread not only parasitic diseases, but also bacterial and viral ones to new regions. Therefore, it is important to monitor and describe various cases of disease. In central Poland, in the Turek Forest District near Konin, migrating wolves have been seen since 2018. Most often, the length of stay of a given individual in the forest district is short and lasts from one to three days. Their appearance is most often registered by the recordings of photo-traps installed at waterholes and by direct observations of forestry services.

Our announcement concerns a male wolf whose stay in the Turek Forest District, where life observations were made and recorded at the beginning of May 2020 by a camera trap. The individual weighing $28 \mathrm{~kg}$ has completed via first year of life. Its age was estimated based on the methods proposed by Landon et al. [3]. The animal showed unusual behavior and was found dead after a few days.

\section{Material and Methods}

For behavioral research, a camera trap was used, for which a Browning Spec Ops Advantage camera equipped with a motion sensor was used. It was installed near a forest natural water reservoir. After a preliminary inspection of the dead wolf, it underwent radiological test. Digital radiography was made using an EXAMION DR Maxivet Co. X-ray that applied tube voltage of $46 \mathrm{kV}$ in the tube current-exposure time of $10 \mathrm{mAs}$. Then, dissection was performed under prosectorial conditions and changes in internal organs were assessed. For histopathological examinations, lung sections were taken from which sections were made using the paraffin method and routinely stained with hematoxylin and eosin, the Rapi Hem kit and the Gram method. Moreover, the pleural effusion was centrifuged, and smears stained with the Rapi Hem kit and the Gram method were made from the obtained feces.

\section{Results and Discussion}

The camera trap recorded the presence of a wolf for the first time in the Turek Forest District on May 4, 2020, just after midnight. The last recording took place on May 5 at 5:57 p.m. From the time it appeared until its disappearance, the wolf was recorded at the waterhole five times during this time, but it is not certain that it did not use water also in other places where there was no camera trap. He was found dead on the morning of May 7, a few hundred meters from the waterhole (SM. 1). The animal's incoherent movements indicated a very severe exhaustion. The animal was clearly weakened and tired. The video also revealed symptoms of dyspnoea. The animal showed limited ability to step out, both with the thoracic and pelvic limbs. The gait was asymmetrical. (Fig. 1). The loading on the limbs was careful and very slow. The animal manifested clearly visible pain symptoms especially when withdrawing from water after quenching. The time spent at the waterhole was from two to seven minutes. (SM. 2-4).

Imaging diagnostics in the form of x-rays did not reveal any mechanical osteological damage in the area of the axial or limb skeleton. There were no other pathological changes within the locomotor apparatus or the presence of foreign bodies (e.g., projectile fragments).

Post-mortem examination revealed approximately $2,000 \mathrm{ml}$ of cloudy, blood-tinged fluid in the pleural cavity (Fig. 2). Lungs were slightly sunken, unevenly supplied with blood, dripping on the cross-section with serous exudate with dark red venous blood. The pulmonary and parietal pleura was dull, rough, and discolored by hemoglobin. The right heart ventricle was dilated. Peritoneal cavity was free of pathological contents. The liver and kidneys showed signs of degenerative changes. Spleen was of normal size and shape.

Microscopic examination indicated areas of fibrin and superficial necrosis on the surface of the pulmonary pleura, forming homogeneous eosinophilic masses with debris of damaged cells. Under the pleura there was an inflammatory infiltration composed of mononuclear cells with higher or lower amount of fibroblasts (Fig. 3). The lung tissue itself showed moderate congestion and the presence of the edema fluid in the alveolar lumen. Slight areas of follicular emphysema were locally visible. There were no signs of an inflamation in the bronchial walls and interstitial tissue. In the slides, prepared from lung tissue stained with the "RapiHem" kit, more or less numerous streptococci were visible adjacent to the pleural surface. In smears from the pleural sludge, apart from exfoliated pleural cells, gram-positive cocci, arranged in characteristic chains with the phenotype of Streptococcus sp., were seen as well as single bacteria with morphological features of Enterococcus sp. (Fig. 4). 

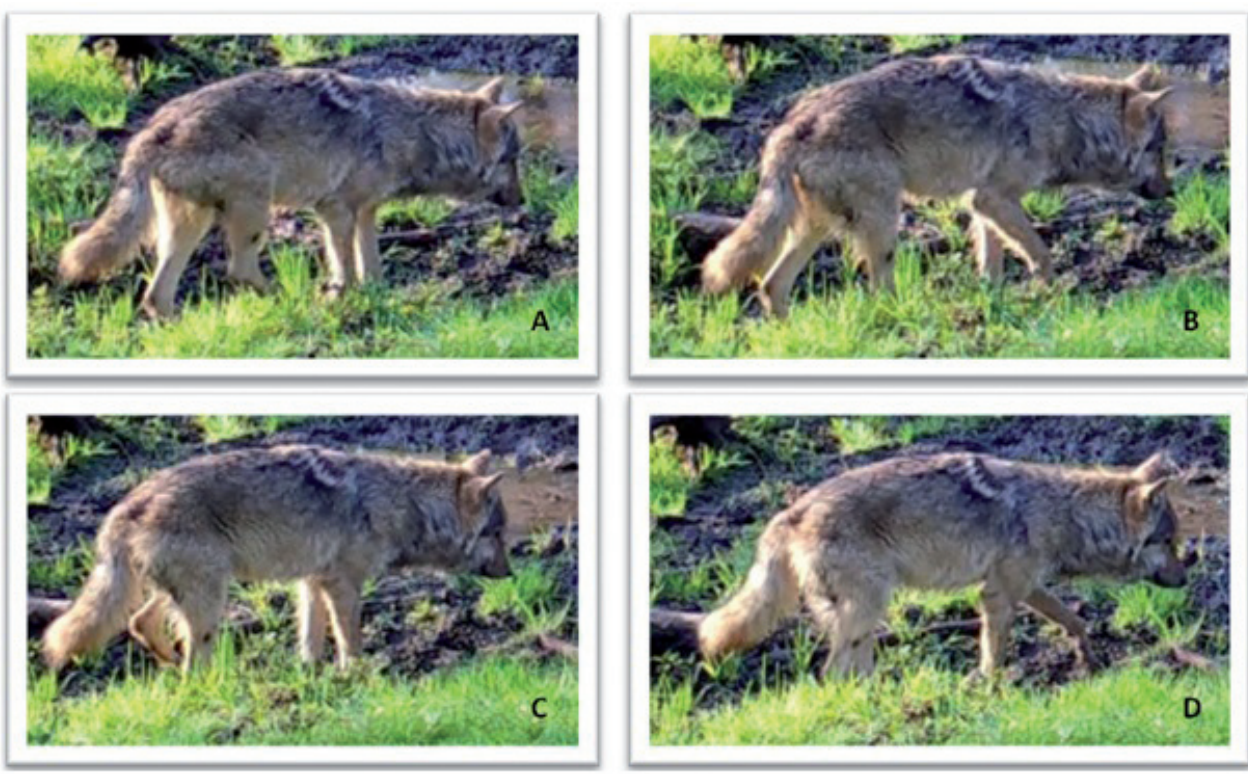

Fig. 1. Irregular movement.

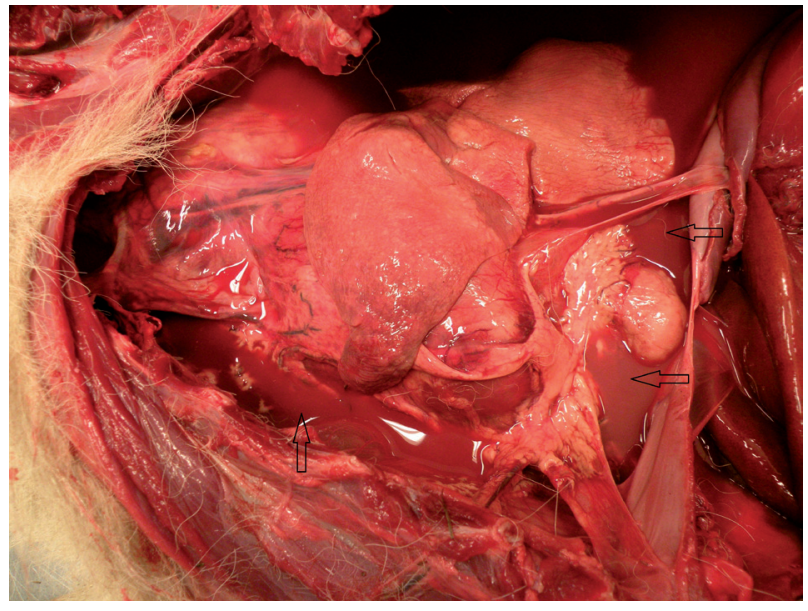

Fig. 2. A cloudy, blood-colored fluid filling the pleural cavity.

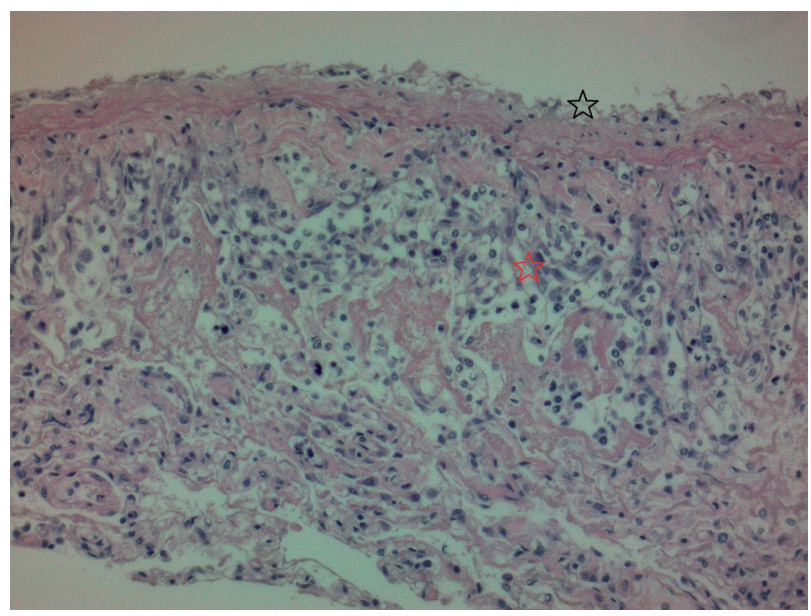

Fig. 3. Areas of superficial pleural necrosis (black asterisk). Fibrosis and inflammatory cell infiltration (red asterisk) in the subpleural tissue (H\&E. Magnification $200 \mathrm{x}$ ).
Inflammatory pleural changes in Canidae are not very common. They are usually bacterial infections, most often mixed [4]. In dogs, a common opportunistic pathogen of the upper respiratory tract, intestines and the urogenital system is Streptococcus spp. In conditions of weakened defense mechanisms, it may cause local inflammatory reactions, bacteraemia or toxemia [5] and inflammatory processes in the lungs [6]. Streptococcus spp. can be also considered as primary pathogen [7]. Sometimes pleurisy is associated with a perforation of the esophagus or the migration of foreign bodies through the bronchial pathway [7-9] or by penetrating the chest wall. Several years ago we observed a case of pleurisy in the red fox caused by migration of a spruce branch through the bronchi and perforation of the pleura (unpublished material). Foreign bodies, e.g.

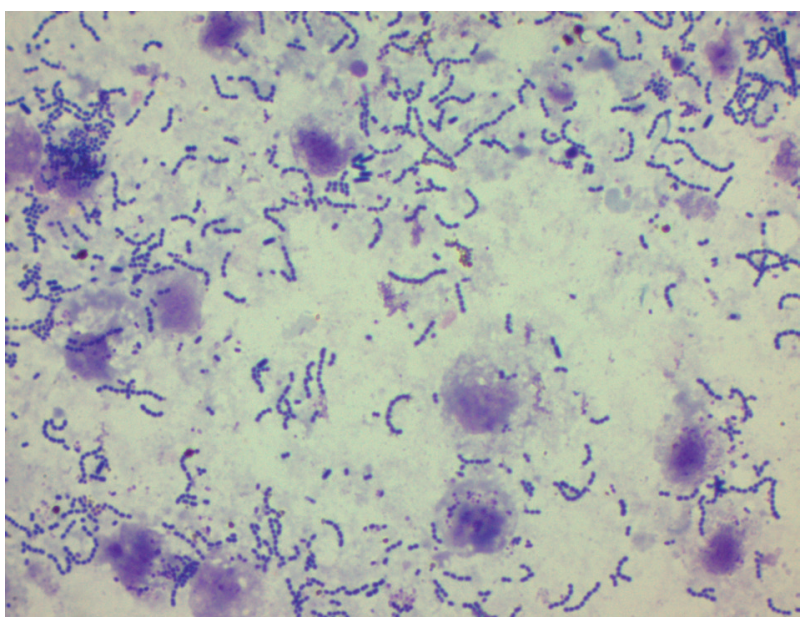

Fig. 4. Pleural sediment. Exfoliated mesothelial cells and gram-positive cocci in chains (RapiHem, Magnification $1000 \mathrm{x})$. 
plant parts, carry microorganisms that may be part of the oropharyngeal flora (including Streptococcus spp.), the skin surface or soil bacteria [9]. In the observed case, the image of the lesions seems to indicate that the pleural inflammation process was primary, because the lungs showed only signs of congestive hyperemia and edema, the continuity of the esophagus was maintained, and no foreign bodies were found in the bronchi. Radiological examination also ruled out mechanical damage to the chest walls as a result of a traffic accident or a gunshot. The microscopic changes indicate the chronic nature of the inflammatory process, that is, the animal was probably ill for more than two weeks. The wolf was observed only for four days and showed disease symptoms already on the first day of observation. Therefore, it can be assumed that it was a weaker specimen rejected by the pack that migrated alone through Central Poland. Young wolves spend the first year of their life together with the pack. However, in the spring of the following year, they gradually leave the pack in search of their own territory. This is especially true for males. There may be several reasons for this phenomenon. To a large extent, these are social factors, and in particular the increasing sexual competition between males [10]. Young wolves try to pair with wolves from other groups to start their own packs, thus avoiding competing within the family group [11]. This promotes the diversification of the genetic material by combining individuals from different packs [12]. Moreover, individuals standing the lowest in the social structure may not be allowed to prey, and they decide to leave the pack in order to search for food by themselves [13].

\section{Conclusions}

Such a situation could have arisen in the case of the male we studied, who had to migrate as a one-year-old male. The stress of loneliness, and presumably also the increasing nutritional deficiencies, were undoubtedly a strong factor that decreased the animal's immunity and allowed the excessive multiplication of opportunistic bacteria, which ultimately caused fibrin-hemorrhagicnecrotizing diffuse pleurisy and death. The Turek Forest Inspectorate is located in Central Poland and covers the eastern part of Greater Poland (Wielkopolska) and the western part of the Lódź Province. This location is important due to the possible intersection of wolf migration routes of different populations, which may be carriers of pathogenic bacterial strains. Registering such cases can supplement the knowledge about the ecology of this valuable mammalian species as well as contribute to the study of disease spread among freeliving animals.

\section{Acknowledgements}

The research was co-financed within the framework of Ministry of Science and Higher Education program as "Regional Initiative Excellence" 2019-2022, Project No. 005/RID/2018/19.

\section{Conflict of Interest}

The authors declare no conflict of interest.

\section{References}

1. SZEWCZYK M., NOWAK S., NIEDŹWIECKA N., HULVA P., ŠPINKYTĖ-BAČKAITIENE R., DEMJANOVIČOVÁ K., BOLFÍKOVÁ ČERNÁ B., ANTAL V., FENCHUK V., FIGURA M., TOMCZAK P., STACHYRA P., STĘPNIAK K.M., ZWIJACZ-KOZICA T., MYSŁAJEK R.W. Dynamic range expansion leads to establishment of a new, genetically distinct wolf population in Central Europe. Scientific Reports. 9 (1), 19003, 2019.

2. REINHARDT I., KLUTH G., NOWAK S., MYSŁAJEK R.W. A review of wolf management in Poland and Germany with recommendations for future transboundary collaboration. BfN-Skripten, 356, 2013.

3. LANDON D.B., WAITE C.A., PETERSON R.O., MECH, L.D. Evaluation of Age Determination Techniques for Gray Wolves. The Journal of Wildlife Management. 62 (2), 1998.

4. LAMM C.G., FERGUSO A.C., LEHENBAUER T.W., LOVE B.C. Streptococcal infection in dogs: A retrospective study of 393 cases. Veterinary Pathology. 47 (3), 2010.

5. JAEGER G., SKOGMO H.K., KOLBJØRNSEN O., LARSEN H.J.S., BERGSJØ B., SØRUM H. Haemorrhagic pneumonia in sled dogs caused by Streptococcus equi subsp. zooepidemicus - one fatality and two full recoveries: a case report. Acta veterinaria Scandinavica. 55, 2013.

6. YAMADA N., HASHIMOTO S., TOMONARI Y., KOKOSHIMA H., DOI T., SATO J., WAKO Y., TSUCHITANI M. Bacterial pleuritis with thickened mesothelial hyperplasia in a young beagle dog. Journal of Toxicologic Pathology. 26 (3), 2013.

7. FLISI S., DALL'AGLIO M., SPADINI C., CABASSI C.S. QUINTAVALLA F. Microbial Isolates from Vegetable Foreign Bodies Inhaled by Dogs. Veterinary Medicine International. 2018. 2018.

8. LÓPEZ A., MARTINSON S.A. Respiratory System, Mediastinum, and Pleurae. In Pathologic Basis of Veterinary Disease $6^{\text {th }}$ ed.; ZACHARY, J. F., Elsevier, St. Louis, Missouri, USA, 557, 2016.

9. COMBS M., HICKS A., YOUNG P., GIBBONS G., LORD J., EDWARDS G., D GOLLAND D., MICHELSEN J., RAIDAL S., DAVIES S., MALIK R. Grass seed foreign body-related disease in dogs and cats: A wide spectrum of clinical presentations. Australian Veterinary Practitioner. 47 (1), 13. 2017

10. OKARMA H. Wilk. Wydawnictwo Edukacyjno-naukowe $\mathrm{H}_{2} \mathrm{O}$, , Bibice, Poland, 304, 2015 [In Polish]. 
11. CORDONI G., PALAGI E. Back to the Future: A Glance Over Wolf Social Behavior to Understand Dog-Human Relationship. Animals. 9, 991, 2019.

12. HULVA P., ČERNÁ BOLFÍKOVÁ B., WOZNICOVÁ V., JINDŘICHOVÁ M., BENEŠOVÁ M., MYSŁAJEK R. W., NOWAK S., SZEWCZYK M., NIEDŹWIECKA N., FIGURA M., HÁJKOVÁ A., SÁNDOR A.D., ZYKA V.,
ROMPORTL D., KUTAL M., FINĎO S., ANTAL V., Wolves at the crossroad: Fission-fusion range biogeography in the Western Carpathians and Central Europe. Diversity and Distributions. 24 (2), 2018.

13. MECH L.D., BOITANI L. Wolf social ecology. In: Wolves: Behavior, Ecology, and Conservation. University of Chicago, Press, Chicago. USA, 472, 2003.

\section{Supplementary Material}

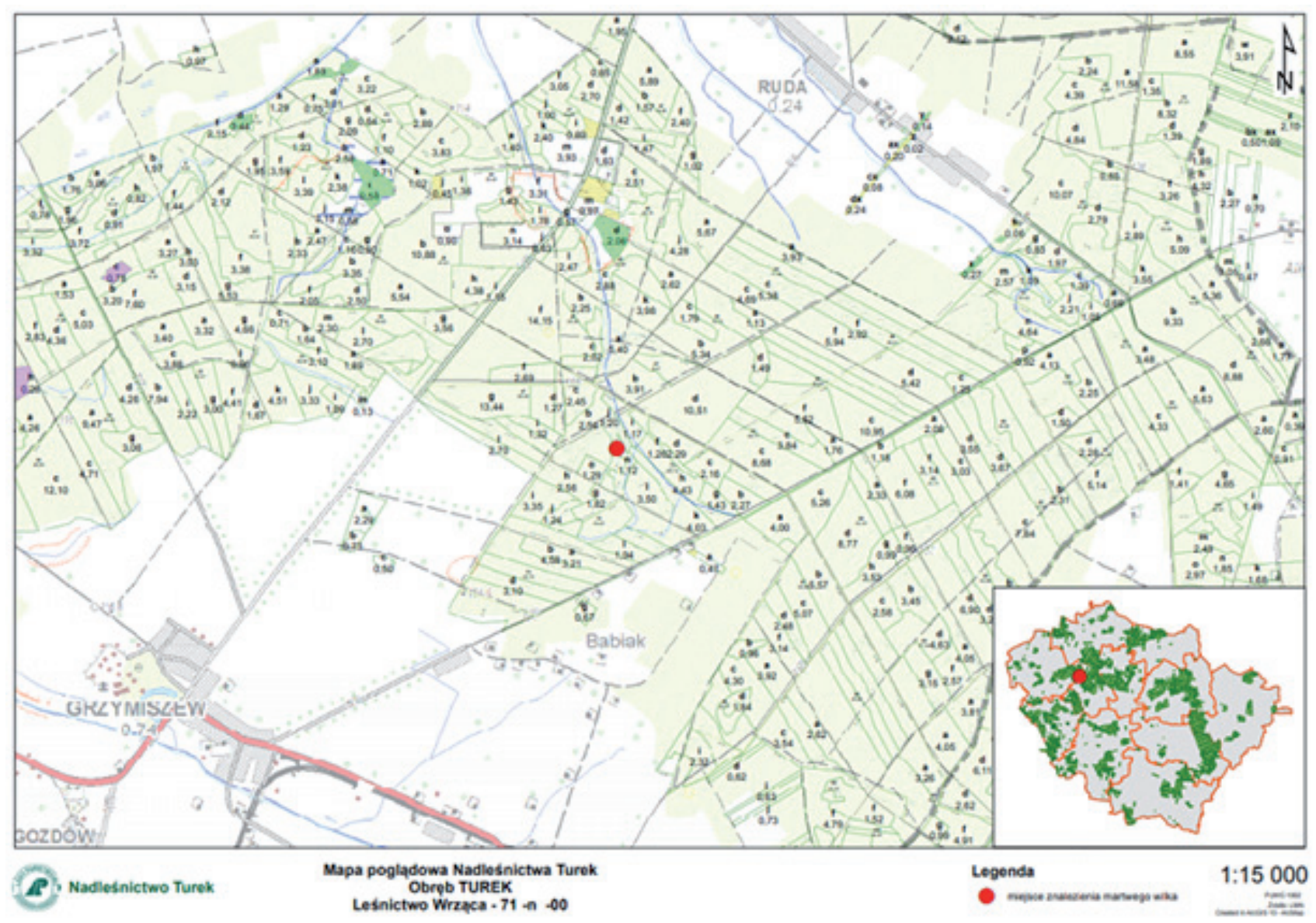

SM 1. A map- the place where the dead wolf was found.

SM 2-4. Photo trap recording

http://www.pjoes.com/SuppFile/135829/5270/4632a54d5ebc3332b4de6baa5a09e170/ http://www.pjoes.com/SuppFile/135829/5271/b7e25db258d2f27929c6c9cc11e2a9c5/ http://www.pjoes.com/SuppFile/135829/5272/dac3d212e19dae43ef20c8052760a4b8/ 